\title{
Towards Digital Constitutionalism? Mapping Attempts to Craft an Internet Bill of Rights
}

\section{Citation}

Gill, Lex, Dennis Redeker, and Urs Gasser. 2015. "Towards Digital Constitutionalism? Mapping Attempts to Craft an Internet Bill of Rights." Berkman Klein Center for Internet \& Society

Research Publication 2015-15.

\section{Permanent link}

http://nrs.harvard.edu/urn-3:HUL.InstRepos:28552582

\section{Terms of Use}

This article was downloaded from Harvard University's DASH repository, and is made available under the terms and conditions applicable to Other Posted Material, as set forth at http:// nrs.harvard.edu/urn-3:HUL.InstRepos:dash.current.terms-of-use\#LAA

\section{Share Your Story}

The Harvard community has made this article openly available.

Please share how this access benefits you. Submit a story.

Accessibility 
Research Publication No. 2015-15

November 9, 2015

\author{
Towards Digital Constitutionalism? \\ Mapping Attempts to Craft an Internet Bill of Rights
}

\author{
Lex Gill \\ Dennis Redeker \\ Urs Gasser
}

This paper can be downloaded without charge at:

The Social Science Research Network Electronic Paper Collection:

Available at SSRN: http://ssrn.com/abstract=2687120

23 Everett Street - Second F1oor - Cambridge, Massachusetts 02138

$+1617.495 .7547 \cdot+1617.495 .7641$ (fax) • http://cyber.law.harvard.edu. cyber@1aw.harvard.edu 


\section{Towards Digital Constitutionalism? Mapping Attempts to Craft an Internet Bill of Rights ${ }^{1}$}

Lex Gill, Dennis Redeker, Urs Gasser

\footnotetext{
${ }^{1}$ For the full pinpointed reference table used for these observations, please refer to: https://docs.google.com/spreadsheets/d/1uCKs0POcc3fLi1wVuAZjWLmVHztD6VHVCEumlByxRcU/edit?usp =sharing
} 


\section{Table of Contents}

I. Introduction ..............................................................................................................................................2

II. PART ONE: Definition and Methodology ………….........................................................2

III. PART TWO: Rights, Principles, and Core Themes........................................................6

IV. PART THREE: Observations.......................................................................................10

A. Political Communities and Sites of Intervention .........................................................................10

B. Key Actors and Deliberative Processes .............................................................................13

C. Substantive Content............................................................................................................................16

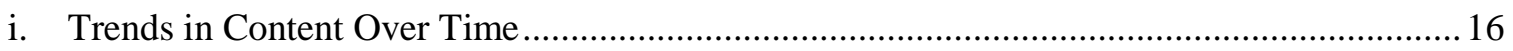

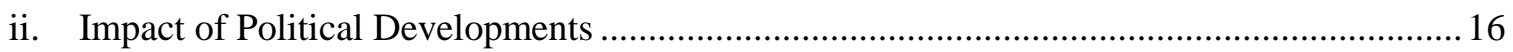

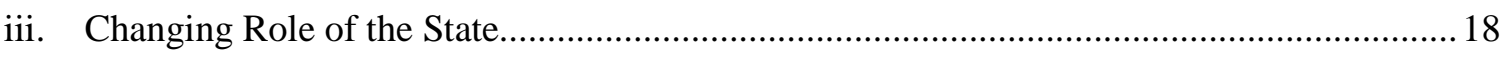

V. PART FOUR: Looking Forward \& Future Research Questions .................................19

Bibliography .........................................................................................................................................22 


\section{Introduction}

The idea of an "Internet Bill of Rights" is by no means a new one: in fact, serious efforts to draft such a document can be traced at least as far back as the mid-1990s. Though the form, function and scope of such initiatives has evolved, the concept has had remarkable staying power, and nowtwo full decades later-principles which were once radically aspirational have begun to crystallize into law. In this paper, we propose a unified term to describe these efforts using the umbrella of "digital constitutionalism" and conduct an analysis of thirty initiatives spanning from 1999 to 2015. These initiatives have great differences, and range from advocacy statements to official positions of intergovernmental organizations to proposed legislation. However, in their own way, they are each engaged in the same conversation, seeking to advance a relatively comprehensive set of rights, principles, and governance norms for the Internet, and are usefully understood as part of a broader, proto-constitutional discourse. While this paper does not attempt to capture every facet of this complex political behaviour, we hope to offer a preliminary map of the landscape, provide a comparative examination of these diverse efforts toward digital constitutionalism, and-most importantly - provoke new questions for further research and study. The paper proceeds in four parts, beginning with a preliminary definition for the concept of digital constitutionalism and a summary of our research methodology. Second, we present our core observations related to the full range of substantive rights, principles and themes proposed by these initiatives. Third, we build on that analysis to explore their perceived targets, the key actors and deliberative processes which have informed their character, and the changes in their substantive content over time. Finally, we look forward, identifying future directions for research in this rapidly changing policy arena and for the broader Internet governance community.

\section{PART ONE: Definition and Methodology}

We make the tentative proposal for "digital constitutionalism" as a common term to connect a constellation of initiatives that have sought to articulate a set of political rights, governance norms, and limitations on the exercise of power on the Internet. Such documents can be traced back at least twenty five years, with authors that include international political bodies, national governments, technology firms, civil society groups and some of the world's most influential leaders in Internet governance. Despite their enduring nature and potentially vast political implications, there has been very limited systematic scholarship on this phenomenon. In order to begin to fill this gap, we have reviewed a set of thirty diverse efforts, each of which seeks to articulate or advance a set of rights, principles, and governance norms for the Internet. Rather than produce an exhaustive directory, we have attempted to select the most representative and influential samples for discussion. The collection spans two and a half decades, from the oldest document in 1999 (the People's Communication Charter $^{2}$ ) to mid-2015, including some documents so recent that they remain in draft format. ${ }^{3}$

Constitutions define the fundamental rules and processes of a political community, and classically, the term refers to those mechanisms which delimit the boundaries of a state's power over its citizens. The core substantive aspect of constitutionalist thinking is embodied in that need to control, limit, and restrain state power, but constitutions also serve a fundamental empowering

\footnotetext{
2 “People's Communication Charter," People’s Communication Charter Coalition, last modified December 22, 1999, http://www.pccharter.net/charteren.html.

${ }^{3}$ See e.g., "Declaration of Internet Rights," Camera dei deputati [Italy], last modified July 28, 2015, http://www.camera.it/application/xmanager/projects/leg17/commissione_internet/testo_definitivo_inglese.pdf.
} 
function: establishing institutions that enable coordination and collective action. ${ }^{4}$ Critically, in the models and documents we explore in our research, these substantive values, problems and principles of constitutionalism are undeniably present. ${ }^{5}$ However, the other core dimension of constitutionalism is the foundational and primary position of constitutional rules within a hierarchy of legal norms. ${ }^{6}$ It is therefore important to state at the outset that our use of the term "constitutional" is not intended to describe how these documents are situated within a set of legal authorities, nor is it meant to suggest that the documents studied are in fact "constitutions" in the classical legal sense. Rather, the term has been adopted here as a powerful shorthand to capture the common thread which binds a set of otherwise divergent initiatives; that each one seeks to engage with political rights, governance norms, and limitations on the exercise of power on the Internet in some fundamental way. They might turn out to be, in other words, "pre-" or "proto-constitutional" documents in the sense of intellectual building blocks for the constitutional material of the digital sphere, ${ }^{7}$ while lacking any preeminent status within a hierarchy of legal rules. Even in this nascent stage however, these initiatives have powerful political and symbolic value to governments, the international community, and those engaged in Internet governance. Moreover, we observe that the Marco Civil-along with others that seek to follow in its footsteps - may provide the first signs that the values advanced in these documents will tend toward legal formalization at all levels. Whether a trend toward codification is ultimately beneficial for Internet freedom remains to be seen, but speaks to a fundamental tension between the desire to govern the Internet and the imperative to impose limitations on the power of those who seek to do so.

We have identified four dimensions which allow us to characterize these documents as belonging to the shared conversation of digital constitutionalism. First, and most importantly, their substantive content addresses broad and fundamental political questions that have an inherently constitutional character; they explore rights (whether collective or individual), articulate limits on state power, and advance a range of governance norms. Second, the initiatives speak to a particular and defined political community, whether explicitly or implicitly. Third, the principles they advance aspire toward a formalized political recognition and legitimacy within that political community. Finally, efforts toward digital constitutionalism exhibit a degree of comprehensiveness. Together, these four criteria aim to provide a framework that is flexible and which accommodates the landscape's diversity. We anticipate that future work will refine these boundaries further and below, we explore each in more detail.

In terms of substantive content, these efforts may involve the extension of established civil rights to the digital sphere; for example, by seeking to guarantee freedom of association on the Internet. They may also include the articulation of rights and freedoms which appear native to the digital environment - though whether such rights are entirely "new" is a matter of some debate. For example, principles of net neutrality — an explicitly digital collection of rights — might be read as the

\footnotetext{
4 Jeremy Waldron, “Constitutionalism: A Skeptical View”, Scholarship @ Georgetown Law (Georgetown University Law Center, 2010), accessed 4 November 2015, http://scholarship.law.georgetown.edu/cgi/viewcontent.cgi?article=1002\&context=hartlecture, 13 and 20. ${ }^{5}$ As are, though to a lesser extent, secondary rules that seek to provide procedural mechanisms for managing that power (in the form of certain governance frameworks, multistakeholder models, and so on).

${ }^{6}$ See e.g., H. L. A. Hart, The Concept of Law (2 ${ }^{\text {nd }}$ Edition, Oxford, Clarendon Press, 1998), 79-91; Wil Waluchow, "Constitutionalism," in The Stanford Encyclopedia of Philosophy, ed. Edward N. Zalta (Spring 2014 Edition), accessed November 4, 2015, http://plato.stanford.edu/archives/spr2014/entries/constitutionalism/.

${ }^{7}$ One possibility is that these documents may be the historical antecedents or precursors to entrenched rules of the future, e.g., in the sense of Bernard Schwartz's approach in The Roots of the Bill of Rights (New York: Chelsea House Publishers, 1981).
} 
logical translation of established and entrenched protections against censorship or discrimination. Similarly, emerging European advocacy surrounding the right to be forgotten may be a comparatively new issue in the field of Internet governance, but has deep intellectual roots in the civilian legal tradition's conception of personality rights. ${ }^{8}$ Other rights, including the proposed right to Internet access itself, ${ }^{9}$ are undeniably specific to the technological environment. In either case, efforts toward digital constitutionalism may include initiatives which advance novel rights specific to the digital environment, or at least seek to adapt existing legal principles to new technological contexts. Governance norms and debates surrounding the limits of state power-including issues of participation, rule of law, democracy, stakeholder representation or political accountability - also help to form the substantive basis of digital constitutionalism. While more process-oriented issues of governance are sometimes more subtly expressed when compared to explicit affirmations of individual rights and freedoms, they are doubtlessly present and critical to the literature.

The second element is that of a political community to which the initiative speaks; in other words, the arena in which it seeks the political recognition of its substantive content. In most cases, this community is made clear by the nature of the actor or type of document (a proposed bill in the Philippines seeks to apply to citizens of the Philippines, declarations of the United Nations seek to apply to its member nations, and so on). Given that the Internet is not neatly bound by national borders, we observe that some of the documents studied fail to explicitly "spell out" the political communities to which they seek to apply. Nevertheless, we have found that even in cases where the scope of intended applicability is not explicit, a contextual reading makes it clear that the document's authors simply perceive the principles to be universal and international in scope. ${ }^{10}$

A third aspect is whether the proposal aspires toward formal recognition and legitimacy within the political community to which it speaks. This element should be interpreted with some flexibility, as it is not our intention to argue that the only efforts which constitute digital constitutionalism are formalized legislative proposals. Rather, the initiatives must simply seek to advance the principles they espouse into the realm of political legitimacy in some concerted way. They need not be drafts to be codified in verbatim, but there must be the sense (whether the document is an international declaration or an activist manifesto) that its authors seek both a formalized recognition of its contents and-at least theoretically—some mode of enforcement. In this paper, we have limited the site of formal recognition to the state and the international governance community, though in some cases, the desired site may in fact be corporate policy. Such efforts (e.g., the Bill of Rights for Users of the Social Web and the Social Network Users' Bill of Rights ${ }^{11}$ ) are discussed briefly in this paper but have not been included in our collection of thirty initiatives.

The fourth element we have set out is a degree of comprehensiveness. Exercises in digital constitutionalism are often aspirational rather than descriptive, and tend to articulate broad moral, philosophical and legal principles rather than a narrow policy agenda. Statements focused on a

\footnotetext{
8 Jeffrey Rosen, "The Right to Be Forgotten," Stanford Law Review Online 64 (2012): 88-92.

${ }^{9}$ David Rothkopf, "Rights 2.0," Foreign Affairs 210 (2015): 66-7.

${ }^{10}$ There is a connected issue here which might be described as a kind of jurisdictional problem. Given the proliferation of the Internet of Things and a deepening ambiguity between on and offline life, are these initiatives best explored as governing documents for rights "on the Internet," or more expansively, rights for an Internet era? For most of the initiatives studied in this paper, the authors' intentions with regard to this question are difficult to determine.

11 "A Social Network Users' Bill of Rights," Christina M. Gagnier and Gagnier Margossian (Computers, Freedom and Privacy Conference), last modified March 26, 2011, http://www.w3.org/2011/trackprivacy/papers/GagnierMargossian.pdf.
} 
singular, narrow issue (for example, net neutrality, or freedom of expression) have therefore been excluded - both from our definition and from our data set - in favour of those which attempt to address digital rights and principles in some comprehensive manner. Examples of advocacy efforts or policies that we excluded for this reason include the Madrid Privacy Declaration, ${ }^{12}$ Norway's Guidelines for Internet Neutrality ${ }^{13}$ and the Electronic Frontier Foundation's Bill of Privacy Rights for Social Networks. ${ }^{14}$ At the same time, we have been careful to ensure that this criteria does not inadvertently exclude efforts that remain meaningfully comprehensive while strategically prioritizing the visibility of certain rights over others (for reasons of urgency or political salience, for example). By requiring that the effort strive for some manner of comprehensiveness, we have also been able to better compare what has been intentionally included and excluded from various initiatives, appreciate small differences, and evaluate trends over time with greater accuracy.

The four dimensions set out above help us to better evaluate whether an initiative can be meaningfully described as an exercise in digital constitutionalism. However, in determining the boundaries of inclusion for the purposes of this paper, we have also sought to evaluate the nature of each document's source. Thus, the initiatives we have selected were included on the basis that they represented the views of an organization, coalition, state or other organized group of some kind. This distinction was made to avoid lending undue space to the views of singular individuals when weighed alongside larger collective efforts. There are simply countless personal manifestos, blog posts and think pieces available online that express specific individuals' visions for digital rights and freedoms, and to attempt to collect or analyze all such efforts systematically would be impracticable. We nevertheless recognize the importance of certain specific works in the discourse-for example, John Perry Barlow's 1996 Declaration of the Independence of Cyberspace has been undeniably influential to subsequent collective projects - and we duly refer to such outputs in our analysis without treating them as part of the data set.

With this framework set out, we conducted a review of relevant material from a range of sources, including search engines, academic databases, digital archives and previous research efforts at the Berkman Center. ${ }^{15}$ Given that there is no common nomenclature for this class of material, the research process included a vast range of terms and sought to capture all manner of "Internet Bills of Rights," "Internet Charters," "Magna Cartas for the Internet" and so on. Sixty per cent of the initiatives are from 2012 or later, likely in part due to the practical reality of poor digital archiving alongside a burgeoning engagement in the area of digital rights. The end result is a collection of thirty initiatives which continue to vary widely in terms of their authorship, procedural aspects, style and substance. The list strives to be meaningfully representative of the available material, rather than exhaustive. ${ }^{16}$

Various exercises in categorization were required to conduct our analysis, and, like all such exercises, they have at times involved a degree of nuance, judgment, and interpretation. We have therefore included a full table of the data summarized in this paper in order to increase the

12 "The Madrid Privacy Declaration: Global Privacy Standards for a Global World," Public Voice, last modified November 3, 2009, http://thepublicvoice.org/madrid-declaration/.

13 "Norwegian Guidelines for Net Neutrality," Norwegian Communications Authority, last modified September 4, 2013, http://eng.nkom.no/technical/internet/net-neutrality/net-neutrality.

14 "A Bill of Privacy Rights for Social Network Users," Electronic Frontier Foundation, last modified May 19, 2010, https://www.eff.org/deeplinks/2010/05/bill-privacy-rights-social-network-users.

${ }^{15}$ Here we would like to recognize in particular the work of Rebekah Heacock Jones, Claire McNear and Mayukh Sen at the Berkman Center for Internet \& Society.

${ }^{16}$ See Table 1: 3 Columns; Name of Initiative, Primary Actor(s), Year 
transparency of that decision-making process and in the hopes of providing greater utility to policymakers and researchers.

\section{PART TWO: Rights, Principles, and Core Themes}

In this section, we engage in a closer examination of the nature and content of the digital constitutionalism landscape. We provide an account of the rights, principles and governance norms that emerge from the thirty initiatives studied, emphasizing the flexibility and nuance required in the exercise of categorization. Rather than strive toward extreme granularity, these categories set out below are an attempt to pull together broad themes and articulate common principles. Some themes contain a degree of overlap, or frame similar issues in different lights; a right to access the Internet may also encompass freedom from discrimination on the basis of disability, for example. We therefore believe it is essential to begin with the recognition that not every aspect of an initiative will be neatly contained under a singular heading. Take, for example, the following passage from the Association for Progressive Communications' Internet Rights Charter (2006):

"People communicating on the Internet must have the right to use tools which encode messages to ensure secure, private and anonymous communication." 17

At its most basic level, this passage might be categorized as "a right to use encryption." But is also entails distinct rights to privacy, to security, to anonymity, to transform one's personal data, and to freely use the technology of one's choice. We see countless examples along similar lines: an inherent connection between freedom of expression and anonymity; a deep tension between surveillance and the rule of law; or a complex relationship between a right of access, network neutrality, and economic development. These observations are not unique to our data set. Rather, they are characteristic of rights discourse generally, and perhaps particularly so for rights in the digital sphere. In short, while we have classified the rights and principles articulated by these initiatives to the best of our abilities, a purely quantitative approach cannot tell the whole story. An appreciation of the data requires an understanding that these right and principles are more often than not interconnected, interdependent, mutually reinforcing, and in some cases even in conflict with one another.

Below, we summarize the general range of content represented in each category of rights and principles identified by this study. It may merit clarification that this list is drawn from the data itself, and thus while we do not seek to foreclose the possibility of other constitutional principles at play in the debates surrounding Internet governance (including anti-democratic or rights-restrictive principles, such as the right for governments to engage in warrantless or unjustified surveillance) such rights have simply not emerged in the documents observed here.

For the purpose of simplicity, we have divided our observations into seven broad, thematic categories. Other authors have attempted to create similar frameworks to classify the way digital

17 "Internet Rights Charter," Association for Progressive Communications, last modified November 2006, https://www.apc.org/node/5677. 
rights are expressed in policy documentation, and we have borrowed from those models where appropriate and relevant. ${ }^{18}$

\section{Basic or Fundamental Rights and Freedoms}

- Freedom of speech and expression: Everyone has the right to freely and fully communicate his or her ideas and opinions, and to express his or herself fully on the Internet. The individual has a right not to have that expression censored.

- Freedom of information: Everyone has the right to access information available on the Internet freely and without censorship. This category may also include right to access personal or government information in particular, or the right to share or host information freely.

- Freedom of (religious) belief: Everyone has the right to freedom of religious belief and conscience, and to manifest those beliefs the digital sphere.

- Freedom of association and protest: Everyone has the right to join and leave groups of his or her own choosing. This also may include the collective rights to organize, to group identity, build community, and to engage in collective efforts.

- Right to personal security and dignity: Everyone has a right to personal dignity and security on the Internet, without fear of harassment, violence or other forms of abuse.

- Protection of children: Children have a special right to safety and security online, and governments have an obligation to take steps to protect them from predatory behaviour and abuse.

- Non-discrimination: Everyone has the right to be free from discrimination on the Internet, both in terms of the technical infrastructure (e.g., ensuring universal design principles) and within online communities. Marginalized and at-risk groups must be protected online.

- Cultural \& linguistic diversity: Everyone has the right to create and access content that is culturally and linguistically diverse on the Internet. Everyone has the right to use their own language and script online.

\section{General Limits on State Power}

- Democracy and the rule of law: Those who make decisions related to Internet governance must be accountable to those affected by their decisions. International legal norms and human rights apply on the Internet. All actors who use the Internet, including states and intelligence organizations, must be bound by the law and a respect for human rights.

- Right to due process: Everyone has the right to due process in relation to any claims made against them or in relation to any possible violations of the law.

- Right to legal remedies: Everyone has a right to an effective remedy by the appropriate and competent body for the violation of his or her rights on the Internet.

\section{Internet Governance and Civic Participation}

- Multistakeholder and participatory governance: All sectors of society should be involved in a cooperative, collaborative process of Internet governance. Those affected by decisions about Internet governance should have a right to participation and representation in that process. The Internet is a shared, collective resource for the public benefit.

\footnotetext{
${ }^{18}$ See e.g., Todd Davies, "Digital Rights and Freedoms: A Framework for Surveying Users and Analyzing Policies," Paper presented at the 6th annual Conference on Social Informatics, Barcelona, November 10-13, 2014.
} 
- Transparency and openness: Decisions about Internet governance should be made transparently and openly. Opportunities to participate in the decision making process should be open, publicized, and accessible to newcomers.

- Open Data: Access to information from governments and other decision-making bodies is integral to the democratic process. Open access to public records, publicly funded data, information about state operations and the work of Internet governance bodies is a right.

- Right to participation: Internet access is a precondition for civic participation, both within digital communities and in society at large. Internet access should not be a barrier to participation in society, community, culture, or government processes. Civic participation should be facilitated and enabled by the Internet.

- Digital inclusion: States and other leaders in the ICT community have an obligation to make the Internet an inclusive space for people of diverse identities and with diverse needs. Internet access must be meaningfully universal and accommodate this diversity in practice.

\section{Privacy Rights and Surveillance}

- Privacy Rights: Everyone has a right to privacy. This includes a right to share - and decline to share-information about themselves, know and control who has access to that information, and understand how it is used.

- Data Protection: Third parties, whether corporations or states, have an obligation to protect the privacy rights of the individuals from whom they collect data. They must take appropriate procedural, technical, and legal steps to protect that data from theft, abuse and surveillance.

- Control and self-determination: Everyone has the right to control how their personal data is used, shared, represented, and managed on the Internet. An individual's consent may be required for the use of their personal data, and that consent can be revoked. Individuals have a right to a copy of their personal data and the right to ask for it to be removed by third parties.

- Right to anonymity: Everyone has the right to present their identity as they see fit on the Internet, which includes the right to be anonymous.

- Protection from surveillance: Everyone has the right to be free from unwarranted, arbitrary or unchecked surveillance and interception online. States and intelligence agencies must be bound by the rule of law as it pertains to their activities on the Internet. Everyone has the right to communicate freely and without the threat of surveillance, monitoring, profiling, or other intrusions upon their right to privacy.

- Right to use encryption: Everyone has a right to use technical tools, including all forms of encryption, to protect their right to private and secure communications.

- Right to be forgotten: Everyone has the right to self-determination on the Internet, including a right to determine how personal data about them is shared and represented. This includes a right to request the removal of personal information from websites or search engines, particularly when that information is irrelevant, outdated, harmful, or violates an individual's privacy or dignity.

\section{Access and Education}

- Right to access: The right to access the Internet cannot be denied. This right is often seen as a precondition to all other rights. In some cases this is articulated as a positive obligation for 
states to provide access, ${ }^{19}$ in others it appears as a freedom from arbitrary or discriminatory denial of access.

- Speed and affordability: The right to access the Internet must be meaningfully available to all, which includes a right to access sufficiently fast and affordable internet. Cost should not be a barrier to connectivity. This may also include the principle that states have a responsibility to cooperate in order to ensure greater broadband deployment and connectivity.

- Access and skills in the workplace: Workers have the right to access the Internet in the workplace. Employers have responsibilities to provide fair access, education, and clear policies about how Internet access in the workplace is managed.

- User awareness and education: Everyone has the right to be aware of their rights and obligations online. They have a right to informed decision-making about how they use the Internet. States and private corporations have an obligation to provide transparent information about these rights and obligations.

- Media and digital literacy: Everyone has the right to education and training about the Internet. Digital literacy is a precursor to meaningful access and civic engagement. States have an obligation to promote the development of skills and knowledge related to the Internet.

\section{Openness and Stability of Networks}

- Security of the network: Everyone has the right to safely and securely connect to the Internet. International and cross-sectoral cooperation is required to ensure the security and integrity of the network and its users. Trust and confidence in the network is essential to ensure the full potential of the Internet is realized.

- Net Neutrality: Network providers cannot provide discriminatory service, restrictions or interference on the basis of the origin of data, its format, or its substantive content. Users have a right to be free from discrimination by network providers on the basis of their identity. The neutrality of the network is essential to maintain a fair, open, and generative Internet.

- Open Standards: Technical standards should be open, transparent and interoperable.

- Interoperability and non-fragmentation: Data must be able to flow across borders freely and without discrimination on the basis of geographic location. The Internet must be a globally interconnected and unfragmented space. Digital technology must be designed to ensure interoperability.

- Stability and reliability of the network: The integrity, stability, and resilience of the network must be collectively ensured. Strong international and cross-sectoral cooperation is required to ensure best practices and protect the functionality of the network.

- Free and open source software: Code should be free to use, read, copy, download, share and modify. Individuals have a right to understand and review the technology they use.

- Device Rights: Everyone has the freedom to use the services, applications, hardware, and software of their choice. Everyone has the right to modify the applications, hardware or software they own, and those who manufacture or distribute such technologies should not unfairly restrict that right.

\section{Economic Rights and Responsibilities}

\footnotetext{
${ }^{19}$ See, e.g., "Joint Declaration concerning the Internet," United Nations, Organization of American States, Organization for Security and Co-operation in Europe, African Commission on Human and Peoples' Rights, 2001, at 6(e) https://www.oas.org/en/iachr/expression/showarticle.asp?artID=848\&lID=1.
} 
- Innovation: The Internet is a powerful tool for economic, scientific and cultural innovation. Regulators should not block new technology. Those who engage in illicit activity should be held responsible for that activity rather than those who develop novel platforms.

- Competition: An open economic environment that promotes free competition on the Internet supports innovation and accessibility of services. States should refrain from engaging in anticompetitive practices or supporting the development of monopolies.

- Economic development: The Internet is a powerful tool for economic development and the eradication of poverty, including in the global South. Information and communication technologies can promote economic, environmental, and social sustainability.

- Intellectual Property: Everyone has a right to benefit from their creative work on the Internet. Everyone has the right to choose how their intellectual property is shared, used, distributed, and modified.

- Intermediary liability: Liability for intermediaries should be limited to ensure the free flow of information, promote innovation, and protect fundamental freedoms online. Only those directly responsible for wrongful or illicit activity on the network should be held responsible.

- Corporate responsibility: The conduct of digital service providers has clear implications for human rights on the Internet. These corporations have an obligation to respect and protect those rights, engage in fair contractual dealings, and protect user rights from abuse or abusive surveillance practices.

- Consumer protection: Corporations have a responsibility to deal fairly and honestly with users and respect their rights on the Internet. They must engage in transparent contractual practices and make terms available in plain, accessible language.

\section{PART THREE: Observations}

\section{A. Political Communities and Sites of Intervention}

Fundamentally, we observe that initiatives in the vein of digital constitutionalism target the most relevant perceived sites of power, regardless of whether those sites correspond neatly to preordained political boundaries. For example, a document presented by an Educom [now Educause] task force entitled Rights and Responsibilities of Electronic Learners (RREL) is an early exercise in what might be described as a kind of proto-digital constitutionalism. ${ }^{20}$ The document, drafted in 1992, feels remarkably prescient, identifying a collection of rights related to access, control of personal data, freedom of expression and intellectual property rights that remain contested to this day. ${ }^{21}$ Notably, despite the fact that the RREL uses the term "citizen" to describe rights-bearing individuals, its express intention is to direct the governance of academic institutions vis à vis the Internet, rather than the actions of states themselves (though commentators anticipated that the document would also influence the thinking of US government actors). ${ }^{22}$ In its proper historical context, the decision to target universities rather than the state makes perfect sense; they are-in 1992 - the primary sites of control, power and access for the majority of Internet users.

As issues of power on the Internet have become more complex, global and diffuse, the target of initiatives toward digital constitutionalism has shifted in parallel. By the late 1990s and early 2000s, we observe a proliferation of documents with an explicitly focus on international - rather than

\footnotetext{
${ }^{20}$ Ellen Messmer, "Educom drafts model net 'bill of rights'," Network World, November 16, 1992, 47-48.

${ }^{21}$ Ibid.

22 Ibid.
} 
institutional-governance, including the People's Communications Charter in 1999, the first draft of the Association for Progressive Communications' Internet Rights Charter in 2001-2002, and the World Summit on the Information Society's Declaration of Principles in $2003 .{ }^{23}$ These documents evoke the language of international treaties, conventions, and formal declarations, speaking to the broad policy implications at the intersection of digital technology and human rights. Periodic efforts targeting the international community have continued to develop over time, emerging from small technical working groups and global conference audiences alike. Sir Tim Berners-Lee has also publicly called for a "global constitution" for the Internet as part of an international initiative called the Web We Want. These documents, like the Charter of Human Rights and Principles for the Internet drafted by a UN Internet Governance Forum (IGF) led coalition in 2014, are increasingly advanced by prominent international bodies. ${ }^{24}$

Indeed, almost three-quarters of the initiatives reviewed in this study are international in scope (22 of 30, or 73\%) and they continue to be by far the most prominent and widely available efforts toward digital constitutionalism. Given the nature of the technical infrastructure, the Internet governance community has always required a high degree of multistakeholderism and decentralized collaboration across borders. ${ }^{25}$ Thus, the desire to reject a fragmented approach in favour of a set of generalized and universal principles makes a certain practical common sense. Similarly, the perception that these rights and principles are fundamental to Internet governance tends to run in parallel to the sense that they should transcend national borders.

However, two trends suggest that the perceived sites of power-and, correspondingly, the respective targets of efforts toward digital constitutionalism-are not as universal or international in scope as they may have been in the early 2000s. First, we see a relatively recent emergence of initiatives which specifically target the private sector. Second, we observe a new trend toward efforts to articulate digital rights and principles at the level of domestic state politics.

By the late 2000s, the perceived nexus of private control had shifted from largely non-profit, research-oriented institutions (as characterized in the RREL documentation) and toward private social networking services and virtual communities. Alongside the more prominent international rights discourse, in this period we also observe the emergence of several "Bills of Rights" documents tailored specifically toward these new private actors. These documents identify corporations as the central locus of power and users - rather than citizens or another constituent community - as primary rights-holders. We see this in examples such as the Bill of Rights for Users of the Social Web, presented at the 2007 Data Sharing Summit, ${ }^{26}$ and in the 2010 Social Network Users' Bill of Rights, a

23 “People's Communication Charter," People’s Communication Charter Coalition, last modified December 22, 1999, http://www.pccharter.net/charteren.html; "Internet Rights Charter," Association for Progressive Communications, last modified November 2006, https://www.apc.org/node/5677; "Declaration of Principles," World Summit on the Information Society (ITU), last modified December 12, 2003, http://www.itu.int/wsis/docs/geneva/official/dop.html.

${ }^{24}$ See Table 2: 3 Columns; Name of Initiative, Year, Scope of Application (National/Regional/International). ${ }^{25}$ Urs Gasser, Ryan Budish, and Sarah Myers West, "Multistakeholder as Governance Groups: Observations from Case Studies," Berkman Center Research Publication No. 2015-1, January 14, 2015, http://ssrn.com/abstract=2549270.

${ }^{26}$ John McCrea. "A Bill of Rights for Users of the Social Web (2007)." [authors: Joseph Smarr, Marc Canter, Robert Scoble, Michael Arrington et. al.]. Last modified April 11, 2008.

http://therealmccrea.com/2008/04/11/three-data-portability-related-events-for-your-calendar/; Todd Davies, "Digital Rights and Freedoms: A Framework for Surveying Users and Analyzing Policies," Paper presented at the 6th annual Conference on Social Informatics, Barcelona, November 10-13, 2014. 
document triggered by major privacy policy changes at Facebook and Google that year. ${ }^{27}$ By 2012, even major international governance bodies had begun to direct considerable effort toward understanding the complex relationship between human rights and the privately mediated digital sphere. ${ }^{28}$ The Electronic Frontier Foundation (EFF) has also been a leader in this arena, with a pair of aspirational "Bill of Rights" documents demanding greater privacy for social network users in 2010, and for mobile application users in 2012..$^{29}$ By 2015, the social network Ello had adopted many of these same principles to brand itself as an "anti-Facebook," promoting a Bill of Rights for its users that included terms like "you have the right to see all the data collected about you" and "you have the right to be anyone you want." 30 These documents are concerned with the exercise and limits on private power in virtual communities and private social networks, in the spirit of what Nicolas Suzor has also called "digital constitutionalism"- though the definition he sets out is markedly narrower than the one adopted in this paper. ${ }^{31}$ We observe that initiatives directed toward private sector actors are more likely to be issue-specific rather than meaningfully comprehensive, seeking to address and remedy particular grievances. Moreover, the rights articulated by such documents tend to be thematically in line with what Davies has described as "user data freedoms," those rights which are managed by the (typically private) software platform or environment (for example, privacy or creative control). ${ }^{32}$

In addition to these new private targets, in recent years we have observed a new, and in some ways quite remarkable phenomenon. Of the thirty documents in our data set, two initiatives have a distinctly regional scope (specifically, the African Declaration on Internet Rights and Freedoms and the Council of Europe's Declaration of Internet Governance Principles), and six speak to specific national constituencies (Italy, Brazil, the Philippines, New Zealand, the United Kingdom, and the United States respectively). ${ }^{33}$ From Brazil's Marco Civil da Internet to the Magna Carta for

27 “A Social Network Users' Bill of Rights," Christina M. Gagnier and Gagnier Margossian (Computers,

Freedom and Privacy Conference), last modified March 26, 2011, http://www.w3.org/2011/trackprivacy/papers/GagnierMargossian.pdf.

${ }^{28}$ See e.g., Council of Europe, Recommendation CM/Rec(2012)4 of the Committee of Ministers to member States on the protection of human rights with regard to social networking services, 4 April 2012.

29 “Mobile User Privacy Bill of Rights," Electronic Frontier Foundation, last modified March 2, 2012, https://www.eff.org/deeplinks/2012/03/best-practices-respect-mobile-user-bill-rights; “A Bill of Privacy Rights for Social Network Users,” Electronic Frontier Foundation, last modified May 19, 2010, https://www.eff.org/deeplinks/2010/05/bill-privacy-rights-social-network-users.

30 “The Ello Bill of Rights for Social Network Users," Ello, last modified August 4, 2015, https://bill-ofrights.ello.co/.

${ }^{31}$ Nicholas Suzor, "Digital constitutionalism and the role of the rule of law in the governance of virtual communities," PhD diss., Queensland University of Technology, 2010: 15; see also Brian Fitzgerald, "Software as Discourse," Alternative Law Journal 25; 24(3) 1999: 144.

32 Todd Davies, "Digital Rights and Freedoms: A Framework for Surveying Users and Analyzing Policies," Paper presented at the 6th annual Conference on Social Informatics, Barcelona, November 10-13, 2014: 2, 6.

33 Regional: "African Declaration on Internet Rights and Freedoms," African Declaration Coalition, last modified on August 5, 2015, http://africaninternetrights.org/declaration-container/declaration/; "Declaration by the Committee of Ministers on Internet governance principles," Council of Europe, last modified September 21 2011, https://wcd.coe.int/ViewDoc.jsp?id=1835773; National:

"Marco Civil da Internet [English Translation]," Public Knowledge, last modified May 27, 2014, https://www.publicknowledge.org/documents/marco-civil-english-version; Magna Carta for Philippine Internet Freedom (MCPIF) [English Translation], S. No. 53, 16th Congr. (2014), http://democracy.net.ph/full-text/; "Declaration of Internet Rights," Camera dei deputati [Italy], last modified July 28, 2015, http://www.camera.it/application/xmanager/projects/leg17/commissione internet/testo_definitivo_inglese.pdf; "Internet Rights and Freedoms Bill," Green Party of Aotearoa New Zealand, last modified on April 22, 2014, https://home.greens.org.nz/sites/default/files/internet_rights_and_freedoms_bill_accompanying_document_0.pd 
Philippine Internet Freedom, political actors have begun to codify these formerly visionary, aspirational principles into binding legislation and state-level declarations. Proposals to enshrine digital rights and freedoms in law and state policy have spanned the ideological spectrum: from Pirate Party members in the European Parliament and Greens in New Zealand to UK Liberal Democrats and US Republican Congressmen. ${ }^{34}$ In Italy, where a "constitution for the Internet" had been proposed at least as early as 2006, ${ }^{35}$ the development of the Declaration of Internet Rights (Dichiarazione dei diritti in internet) is now-in 2015-an ambitious and far-reaching state endeavor. This trend suggests that states are increasingly perceived as a site of power and influence over Internet governance, and that more intervention at the level of domestic policy is to be expected. Along with an increased codification of Internet rights at the state level, the ability to make a distinction between "legally binding standards" and "more aspirational principles" ${ }^{36}$ will invariably have an impact on the digital constitutionalism landscape.

\section{B. Key Actors and Deliberative Processes ${ }^{37}$}

About two-thirds (19) of the documents studied can be characterized as advocacy statements, seeking to influence official policy and legislation, while six represent current or proposed legislation. Another five are best described as non-binding official positions or policy statements from state, regional, or international governmental bodies. As shown in Table 3, a large proportion of the sponsoring parties are civil society organizations, coalitions of state actors or public international institutions. A smaller share have been drafted by private sector organizations and industry consortia.

Certain actors stand out as exceptionally engaged in efforts toward digital constitutionalism. The Electronic Frontier Foundation (EFF) and the Association for Progressive Communications (APC) have each acted as major sponsors for two of the documents examined for this study (the Declaration of Internet Freedom and the International Principles on the Application of Human Rights to Communications Surveillance; and the Internet Rights Charter and Internet Rights Are Human Rights respectively). The two organizations have also served as signatories to other initiatives and consistently participate as part of stakeholder groups, which is perhaps unsurprising, given the nature of their organizational mandates.

f; “A Digital Citizen's Bill of Rights," Darrell Issa, last modified on August 5, 2015, http://keepthewebopen.com/digital-bill-of-rights; "Protecting your data online with a Digital Rights Bill," UK Liberal Democrats, last modified on April 11, 2015, http://www.libdems.org.uk/protecting-your-data-onlinewith-a-digital-rights-bill.

${ }^{34}$ Nate Anderson, "New Internet Bill of Rights contender comes from... pirates?" Ars Technica, December 11, 2009, http://arstechnica.com/tech-policy/2009/12/new-internet-bill-of-rights-contender-comes-from-pirates/; "Internet Rights and Freedoms Bill," Green Party of Aotearoa New Zealand, last modified on April 22, 2014, https://home.greens.org.nz/sites/default/files/internet rights and freedoms bill accompanying document 0.pd f; "Protecting your data online with a Digital Rights Bill," UK Liberal Democrats, last modified on April 11, 2015, http://www.libdems.org.uk/protecting-your-data-online-with-a-digital-rights-bill; "A Digital Citizen's Bill of Rights," Darrell Issa, last modified on August 5, 2015, http://keepthewebopen.com/digital-bill-of-rights.

${ }^{35}$ Stefano, Rodotà, "Una Costituzione per Internet," La Repubblica Tecnologia \& Scienze, June 28, 2006, Accessed August 4, 2015, http://www.repubblica.it/2006/06/sezioni/scienza_e_tecnologia/regoleinternet/regole-internet/regole-internet.html.

${ }^{36}$ Rikke Frank Jørgensen, “An Internet Bill of Rights?” In Research Handbook on Governance of the Internet, edited by Ian Brown, Cheltenham: Edward Elgar Publishing, 2013: 369.

${ }^{37}$ See Table 3: 5 Columns; Name of Initiative, Year, Type of Document, Type of Actor, Type of Process. 
While there is a tendency to assume that the conversation is dominated by North American actors and values, there is in fact a broad and transnational discussion at play (for example, the APC represents some 50 organizations from 35 countries). Similarly, we see documents like the Charter for Innovation, Creativity and Access to Knowledge emerge from a 70-member international forum of civil society actors, and, more recently, the development of the NETMundial Multistakeholder Statement. ${ }^{38}$ The Internet Governance Forum has also classically acted as a venue for convergence and consensus-building around Internet rights and principles, in particular through the leadership of its Dynamic Coalition on Internet Rights and Principles, formed following the Hyderabad IGF in 2008. ${ }^{39}$ This coalition has been responsible for drafting the 2014 Charter of Human Rights and Principles for the Internet and boasts a participant list of over 320 members worldwide. ${ }^{40}$ Also in the international arena, working groups and conferences of the Council of Europe, the OECD, the OAS, and the United Nations are present alongside specific fora for issues of Internet policy. ${ }^{41}$ For example, the African Internet Governance Forum convened dozens of actors on the continent, incubating relationships that ultimately resulted in the African Declaration on Internet Rights and Freedoms. ${ }^{42}$ Among private economic actors, we see participation from the World Economic Forum in the form of their Informed Societies: Towards a Code of Conduct for Government Leaders report and their increasing engagement in the Internet governance arena through NETmundial. ${ }^{43} \mathrm{We}$ also observe willingness from private actors in the ICT sector to engage in coalition building on specific issues - the best example of which is likely the Reform Government Surveillance coalition, bringing together Google, Apple, Microsoft, Facebook and other major institutions on the issue of user privacy. ${ }^{44}$

We have also attempted to distill some information regarding the nature of the process by which each document was drafted. Interestingly, only one third of the actors (10) followed a process that could be described as typical or conventional with respect to the nature of their respective internal

38 "Charter for Innovation, Creativity and Access to Knowledge," FCForum, accessed August 5, 2015, http://fcforum.net/en/charter; "NETmundial Multistakeholder Statement," Global Multistakeholder Forum on the Future of Internet Governance, last modified April 24, 2014, http://netmundial.br/wp-

content/uploads/2014/04/NETmundial-Multistakeholder-Document.pdf.

39 "Dynamic Coalition on Internet Rights and Principles," Internet Governance Forum, accessed August 5,

2015, http://www.intgovforum.org/cms/dynamiccoalitions/54-dynamic-coalitions/dc-meetings-2008/72-ibr.

40 Ibid.

${ }^{41}$ See e.g., "Declaration by the Committee of Ministers on Internet governance principles," Council of Europe, last modified September 21 2011, https://wcd.coe.int/ViewDoc.jsp?id=1835773; "Joint Declaration concerning the Internet," United Nations, Organization of American States, Organization for Security and Co-operation in Europe, African Commission on Human and Peoples' Rights, 2001, https://www.oas.org/en/iachr/expression/showarticle.asp?artID=848\&IID=1; "Seoul Declaration to the OECD Ministerial Conference on the future of the Internet economy," Civil Society and the Trade Union Advisory Committee to the OECD, last modified June 16, 2008, http://thepublicvoice.org/events/seoul08/seouldeclaration.pdf; "Internet Rights \& Principles Dynamic

Coalition," Internet Governance Forum (United Nations), accessed August 5, 2015, http://internetrightsandprinciples.org/wpcharter/.

42 "African Declaration on Internet Rights and Freedoms," African Declaration Coalition, last modified on August 5, 2015, http://africaninternetrights.org/declaration-container/declaration/.

43 "Informed Societies: Towards a Code of Conduct for Government Leaders," World Economic Forum, last modified June 21, 2012,

http://www3.weforum.org/docs/WEF_GAC_InformedSocieties_CodeConductGovernmentLeaders_Summary_2 012.pdf.

44 "Global Government Surveillance Reform," Reform Government Surveillance Coalition, accessed August 5, 2015 , http://www.reformgovernmentsurveillance.com/. 
structures. For instance, the Joint Declaration concerning the Internet ${ }^{45}$ was established following a classic process of international cooperation, jointly drafted by the freedom of expression rapporteurs of organizations such as the OAS and the UN. Similarly, the Council of Europe followed a process typical to its organizational structure when adopting the Declaration on Internet Governance Principles $^{46}$ through the Committee of Ministers of the member states. In other words, these are initiatives which have followed a "business as usual" approach to deliberation and drafting.

In contrast, we observe that over half of the documents (17) were developed as the result of some form of larger and more expansive multistakeholder process. Whether through a consensusbased roundtable of representative actors or in an open conference forum, these initiatives are by definition cross-sectoral. A quintessential example of such an effort takes the form of the NETMundial Multistakeholder Statement ${ }^{47}$ which emerged from a 2014 conference in São Paulo, Brazil. The World Economic Forum's Code of Conduct for Government Leaders ${ }^{48}$ is another interesting example; unlike most initiatives in our data set it largely refrains from overt "rights" discourse, but undoubtedly speaks to issues of digital constitutionalism. Led by Forum's Global Agenda Council on Informed Societies - a body that convenes academics, public officials civil society and representatives from business community-it too is an example of a multistakeholder exercise in digital constitutionalism.

Finally, three of the documents represent the output of drafting exercises which are best described as public, crowdsourced, and participatory, with proposals emerging "from the bottom up" and with minimal formalized deliberation, making them distinct from a structured multistakeholder process. Perhaps the most emblematic example of such an initiative is the My Digital Rights ${ }^{49}$ project, an entirely crowdsourced campaign to craft a "Magna Carta for the digital age" led by the British Library. US Congressman Darrell Issa's attempt to draft a "Digital Citizen's Bill of Rights" in an online, collaborative and open format ${ }^{50}$ and Mashable.com's crowdsourced "Digital Bill of Rights for the Internet, by the Internet" 51 are two other examples which have embraced an open and participatory deliberative process. Indeed, the strong tendency of actors to solicit direct public participation and engage in multistakeholder decision-making processes appears to be a compelling hallmark of digital constitutionalism.

\footnotetext{
45 "Joint Declaration concerning the Internet," United Nations, Organization of American States, Organization for Security and Co-operation in Europe, African Commission on Human and Peoples' Rights, 2001, https://www.oas.org/en/iachr/expression/showarticle.asp? artID=848\&IID=1.

46 "Declaration by the Committee of Ministers on Internet governance principles," Council of Europe, last modified September 21 2011, https://wcd.coe.int/ViewDoc.jsp?id=1835773.

47 "NETmundial Multistakeholder Statement," Global Multistakeholder Forum on the Future of Internet Governance, last modified April 24, 2014, http://netmundial.br/wp-content/uploads/2014/04/NETmundialMultistakeholder-Document.pdf.

48 "Informed Societies: Towards a Code of Conduct for Government Leaders," World Economic Forum, last modified June 21, 2012,

http://www3.weforum.org/docs/WEF_GAC_InformedSocieties_CodeConductGovernmentLeaders_Summary_2 012.pdf.

49 “My Digital Rights,” British Library, accessed August 5, 2015, http://www.bl.uk/my-digital-rights.

50 "A Digital Citizen's Bill of Rights," Darrell Issa, last modified on August 5, 2015,

http://keepthewebopen.com/digital-bill-of-rights.

51 “A Digital Bill of Rights for the Internet, by the Internet," Mashable, last modified August 12, 2013, http://mashable.com/2013/08/12/digital-bill-of-rights-crowdsource/.
} 


\section{Substantive Content ${ }^{52}$ \\ i. $\quad$ Trends in Content Over Time}

Our data set provides the groundwork to provide a quantitative analysis of the frequency with which different rights and principles are cited and to analyze those trends over time. At the outset, it is essential to state that the frequency with which a right or principle appears will not fully capture its importance in all cases; for example, the right to be forgotten - a hotly contested topic in the Internet governance community - appears only three times in the full set of initiatives. Nevertheless, as a general rule, the values which occur most frequently are more likely to represent the rights and principles which perceived to be most fundamental, and may help to uncover areas of emerging consensus. In this section, we present findings which highlight those rights which are most frequently articulated, those which appear to be areas of emerging interest and development, and those which have failed to gain momentum over time.

Of the thirty documents analyzed, three distinct rights stand out most prominently by far. We observe that (1) freedom of expression and (2) privacy rights are addressed the most frequently (27 and 26 times respectively) closely followed by the right of access to the Internet ( 24 occurrences). These issues are rooted in some of the earliest initiatives studied, and continue to persist even in the most recent documentation. Given its intimate connection to freedom of expression, it is not surprising that more than two-thirds (22) of the initiatives also explicitly seek to recognize freedom of information as a distinct right. Transparency and openness, both of Internet governance processes and of networks, were also cited as core principles in over two-thirds (22) of the documents. Conversely, certain rights which would appear fundamental in a broader human rights context (such as freedom of religious belief, which appears only twice) receive scare mention in the digital constitutionalism arena.

We have also explored trends over time in order to better understand the possibility of historical change. In some cases time-based trends are inconclusive. We notice, for example, that the right to freedom of religious belief was cited only twice over the 16-year timeframe of this study: once in 2003 and once again in 2014. Similarly, a right to Internet access in the workplace appears sporadically: once in 2002, a second time in 2008, and finally in 2014. However, in other cases we see a much clearer development over time. For example, 2009 was the first year that intermediary liability was mentioned as an issue or principle in any of the documents, but it has appeared frequently and consistently since. Similarly, device-related rights arise several times in the data set, but were only first explicitly mentioned in 2010. We also observe certain relationships between themes: the right to control and self-determination over one's personal data first appeared in 2010 and has consistently increased in prominence in the years that followed. The right to be forgotten, in some ways a logical extension of that self-determination principle, emerged for the first time in 2014, seemingly in parallel. We also observe that certain rights and principles appear to coincide with the nature of the documents in question; for example, the right to due process is most likely to appear in domestic and regional legislation and policy.

\section{ii. Impact of Political Developments}

There is a natural relationship between the political context from which an initiative arises and the shape, scope, and form it ultimately takes. Because efforts toward digital constitutionalism

\footnotetext{
${ }^{52}$ See Table 5: 45 Columns; Name of Initiative, Year, Presence of Rights/Principles for all 42 rights/principles.
} 
almost always seek to change or influence the policy landscape in some fundamental way, we expect that certain issues will be more clearly articulated at critical historical junctures. We predicted that we would see such a trend following one case in particular: the disclosures in 2013 by Edward Snowden. Interestingly, while we observe little discernable trend in the number of initiatives which seek to advance generalized privacy rights following the 2013 Snowden disclosures, our data indicates substantial increases in a number of "peripheral" privacy rights and principles. In particular, we see marked overall increases in the occurrence of the right to data control and self determination, the right to anonymity, the right to use encryption, and the right to explicit protection from government surveillance. Our hypothesis, borne out at least in a preliminary way by this data, is that while the perceived importance of privacy rights was not substantially affected, they are now being articulated in much more specific, sophisticated and nuanced ways than they have been in the past.

This historical moment also provides an excellent case study to examine the underlying motivations which drive these efforts. Overwhelmingly, the initiatives published following the leaks speak either explicitly or implicitly to the issue of mass surveillance, pointing to the idea that there is perhaps the greatest interest in digital rights and freedoms when they are perceived to be at risk. Of the thirteen documents published from 2013 onward in our study, eleven of them address the topic of mass online surveillance directly; for example, the Global Government Surveillance Reform coalition demands that "enforcement and intelligence efforts are rule-bound, narrowly tailored, transparent, and subject to oversight." ${ }^{33}$ Similarly, the Charter of Human Rights and Principles for the Internet insists that "everyone has the freedom to communicate without arbitrary surveillance or interception (including behavioural tracking, profiling, and cyber-stalking), or the threat of surveillance or interception." ${ }^{54}$ The International Principles on the Application of Human Rights to Communications Surveillance is even more explicit, arguing that human rights law must adapt to modern surveillance technology, and that "[n]othing could demonstrate the urgency of this situation more than the recent revelations confirming the mass surveillance of innocent individuals around the world." 55

This tendency to reflect pressing political issues is not unique to the Snowden revelations; other critical debates in the history of Internet governance also emerge at predictable moments. For example, the principle of network neutrality is first asserted in 2006, just as major institutions, including the U.S. Federal Communications Commission, its Supreme Court and its Senate begin to tackle the issue. ${ }^{56}$ Similarly, the World Economic Forum explicitly names "Wikileaks and other forced transparency initiatives," as an influential factor underlying issues of transparency and openness in the digital age following a major series of critical diplomatic cable leaks. ${ }^{57}$ Issues at the core of Internet governance-whether debates surrounding digital copyright reform, trends in

53 “Global Government Surveillance Reform," Reform Government Surveillance Coalition, accessed August 5, 2015, http://www.reformgovernmentsurveillance.com/.

54 “Internet Rights and Principles Charter," Internet Rights and Principles Coalition, accessed August 5, 2015 , http://internetrightsandprinciples.org/wpcharter/.

55 "International Principles on the Application of Human Rights to Communications Surveillance," Necessary and Proportionate, last modified May 2014, https://en.necessaryandproportionate.org/text.

56 "Internet Rights Charter," Association for Progressive Communications, last modified November 2006, https://www.apc.org/node/5677; “A Timeline of Net Neutrality,” Public Knowledge, accessed September 15, 2015, http://whatisnetneutrality.org/timeline.

57 "Informed Societies: Towards a Code of Conduct for Government Leaders," World Economic Forum, last modified June 21, 2012,

http://www3.weforum.org/docs/WEF_GAC_InformedSocieties_CodeConductGovernmentLeaders_Summary_2 012.pdf. 
cybersecurity, and the relationship between technology firms and the state - all invariably find their way into these documents over time, forming milestones along the path of digital constitutionalism.

\section{iii. $\quad$ Changing Role of the State}

A textual analysis also gives us a unique - if somewhat impressionistic - view of how rights discourse in the digital sphere has changed over time. While some have argued that the distinction between negative ("freedom from") and positive ("right to") rights is largely artificial, it may nevertheless provide a useful framework for understanding the shifting role of the state in the digital sphere over the past two decades. In the early days of mainstream Internet use, a kind of cyberlibertarian thinking served as the dominant approach, perhaps best illustrated by the famous words of John Perry Barlow in 1996:

"Governments of the Industrial World, you weary giants of flesh and steel, I come from Cyberspace, the new home of Mind. On behalf of the future, I ask you of the past to leave us alone. You are not welcome among us. You have no sovereignty where we gather." ${ }^{58}$

The idea that the Internet should serve as a radical space for individual liberation and creativity captured the imagination of many digital rights theorists for the better part of the 1990s and early 2000s. In early efforts toward digital constitutionalism, we see these priorities translated wholesale: freedom of expression, and from censorship, is a powerful early priority.

However, since the time of Barlow's Declaration of the Independence of Cyberspace, it has become exponentially more difficult to distinguish between our digital and material lives. The way we engage with the Internet has countless and undeniable consequences for the physical world, and as the distinction between these two spheres becomes less relevant, the idea of a digital "wild West" has also become less tenable. At the same time, skeptics of Barlow's view asked whether it may be preferable to actively intervene before "the absence of regulation ultimately [...] leave[s] the Internet at the mercy of authoritarian regimes or market laws." ${ }^{, 59}$ Increasingly, the need for government intervention, protection of vulnerable groups, and international cooperation in the realm of Internet governance has become a source of consensus.

While it is difficult to track this trend in a quantitative way using the the relatively small data set available to us, ${ }^{60}$ it is abundantly clear in the debates which surround these initiatives. For example, in 2012 a Declaration of Internet Freedom was released by some of the most prominent actors of the digital rights advocacy world at that time (including the Electronic Frontier Foundation,

58 “A Cyberspace Independence Declaration," John Perry Barlow, last modified February 9, 1996, https://w2.eff.org/Censorship/Internet_censorship_bills/barlow_0296.declaration.

${ }^{59}$ Francesca Musiani, "The Internet Bill of Rights: A Way to Reconcile Natural Freedoms and Regulatory Needs?" SCRIPTed: A Journal of Law, Technology and Society 6(2009): 506.

${ }^{60}$ Note: One limitation of our sample is that it can be challenging to see clear-cut trends over time. This is as a result of a few very early (1999-2003) documents included which strive for extraordinary comprehensiveness, mirroring the style and scope of documents such as the UDHR (see, e.g., People's Communication Charter). Later documents tend to be more focused and less comprehensive, making it difficult to evaluate trends consistently until the mid-2000s. It is likely that the narrowing of focus over time is rooted in a concern regarding enforceability; actors may hesitate to articulate rights they do not believe can be meaningfully protected. 
ACCESS, the American Civil Liberties Union, CREDO and endorsements from hundreds of others). ${ }^{61}$ In response, a number of substantially more peripheral groups advanced a competing Declaration of Internet Freedom, critical of the what they perceived as "ambiguit[ies]" in the original document "that could pave the way for more government intervention." ${ }^{2}$ The second Declaration, endorsed largely by American libertarian groups, harkens to a kind of "digital originalism" that has fallen out of favour among most international actors. Francesca Musiani argues that those who advance such a perspective are "missing a vital piece of the picture," and that intervention is needed to "avoid the transformation of the Net into a controlled realm, dominated by a few actors." response to Barlow's original Declaration of the Independence of Cyberspace by Daniel Castro:

"We do not want an Internet governed by the nations of the world, but neither do we want an Internet divorced from government. We seek a balance that recognizes both the rights of the individual and the benefits to the community of well-ordered systems." [...] "We reject your declaration of independence and take up a new call for interdependence among sovereign nations and peoples." ${ }^{\prime 4}$

The proliferation of consortia, fora, working groups, international bodies and advocacy organizations since the time of Barlow's Declaration validate this belief in interdependence and cross-boundary collaboration, as does the emerging trend we have observed toward state-level intervention in the area of Internet rights.

\section{PART FOUR: Looking Forward \& Future Research Questions}

In this paper, we have attempted to initiate a larger conversation regarding the scope of rights and freedoms on the Internet, proposing the concept of digital constitutionalism as a common framework. While this study has sought to remain largely descriptive, we hope that in doing so we have provoked broader questions for analysis, discussion and research.

First, we surveyed and defined those rights and principles commonly captured by efforts toward digital constitutionalism. We sought to articulate the general range of issues and the relationships between them, but a deeper exploration of these themes is both warranted and essential. In particular, the relationship between rights on the Internet and the broader human rights discourse is poorly understood. How to situate "digital" rights and principles (for example, of net neutrality) or those rights with particular digital implications (like the right to be forgotten) within the broader frameworks set out by the Universal Declaration of Human Rights or subsequent treaties and conventions is unclear, though a number of the initiatives we studied have made reference to such documents. ${ }^{65}$ Exploring which rights and principles appear to be most fundamental to the digital

61 "Declaration of Internet Freedom," Free Press and the Free Press Action Fund et al., accessed August 5, 2015, http://www.internetdeclaration.org/freedom.

62 "Declaration of Internet Freedom," Tech Freedom et al., accessed August 5, 2015, http://declarationofinternetfreedom.org/.

${ }^{63}$ Francesca Musiani, "The Internet Bill of Rights: A Way to Reconcile Natural Freedoms and Regulatory Needs?" SCRIPTed: A Journal of Law, Technology and Society 6(2009): 508.

${ }^{64}$ Daniel Castro, "A Declaration of the Interdependence of Cyberspace," Computer World, February 8, 2013, http://www.computerworld.com/article/2494710/internet/a-declaration-of-the-interdependence-of-

cyberspace.html.

${ }^{65}$ See e.g.., "Charter on Human Rights and Principles on the Internet," Internet Rights and Principles Coalition, accessed August 8, 2015, http://internetrightsandprinciples.org/wpcharter/; "The People's Communication 
environment (including the right of access itself) and which may lie on the periphery or blur the line between these two worlds, is also a potentially valuable exercise. ${ }^{66}$ Our findings invite more in-depth research on the intellectual history of these rights and their emerging relationship with technology, including the Internet.

Second, we sought to identify historical trends in digital constitutionalism, observing that efforts seek to intervene in a way which generally conforms to perceived sites of power and authority. We have seen a trajectory from informal, non-binding and aspirational initiatives toward more concrete, sophisticated proposals, some of which have ultimately taken the form of binding legislation or state declarations. In particular, we noted that recent attempts to entrench digital rights and principles at the realm of formal, state-level politics-particularly in Brazil, Italy, and the Philippines - may be mapping out a new frontier for digital constitutionalism. Studying the practical impacts - both of formal legislation, such as Brazil's Marco Civil da Internet and of non-binding declarations such as Italy's Dichiarazione dei diritti in internet-will also help illuminate the full possibilities (and limitations) of these efforts.

An exploration of how these initiatives fit into existing hierarchies of legal norms and principles over time will also support a more developed understanding of where digital rights are best situated in the human rights landscape. Similarly, where these new initiatives run the risk of promoting either legal or technical fragmentation, an understanding of the underlying motivations that drive the trend toward state-level politics will be essential for future actors in the Internet governance community. A deeper study of the competing interests and underlying power relations at playwhether within government, corporate actors and lobbyists, civil society or advocacy groups-will also invariably shed light on the function served by efforts toward digital constitutionalism.

Third, we offered an overview of the core actors in the field of digital constitutionalism and a brief exploration of the processes by which these initiatives originate. The tendency toward open, participatory, and multistakeholder fora was observed throughout the data set, even in very early efforts. These deliberative processes, the values embedded within them, and how those values connect to policy outcomes are all issues which merit further study. In particular, while we see a trend toward openness and inclusion, there are nevertheless challenges around issues of meaningful representation and democracy in a multistakeholder context. ${ }^{67}$ In other words, a careful examination of which voices are excluded, marginalized, or perhaps artificially amplified through these processes is required. ${ }^{68}$ Comparing these efforts to the classic deliberative infrastructure in the human rights field may also be fertile ground for further research. ${ }^{69}$

Charter, ” People's Communication Charter Coalition, last modified December 22, 1999,

http://www.pccharter.net/charteren.html.

${ }^{66}$ Note: Here, we may see parallels to well-developed ideas in the human rights discourse around "first" and "second generation” rights, see e.g. Rikke Frank Jørgensen, “An Internet Bill of Rights?" In Research Handbook on Governance of the Internet, edited by Ian Brown, Cheltenham: Edward Elgar Publishing, 2013. ${ }^{67}$ See e.g.: Jean-Marie Chenou, "Is Internet governance a democratic process? Multistakeholderism and transnational elites" (paper presented at the ECPR General Conference 2011, Reykjavík, Iceland, August 25-27, 2011); Avri Doria, "Use [and Abuse] of Multistakeholderism in the Internet," in The Evolution of Global Internet Governance - Principles and Policies, eds. R. Radu et al. (Berlin: Springer, 2014).

68 Urs Gasser, Ryan Budish, and Sarah Myers West, "Multistakeholder as Governance Groups: Observations from Case Studies,” Berkman Center Research Publication No. 2015-1: 17-20, January 14, 2015, http://ssrn.com/abstract=2549270.

${ }^{69}$ Liddicoat \& Doria (2012) raise interesting questions about process, for example. They review technical standard setting for the Internet and ask "how [...] Internet protocol values could correspond to and affect human rights"? They argue that the major differences are procedural: that technical standards need to evolve constantly 
Finally, we identified a series of trends in terms of the substantive content, including the relationship between political events and the demands and affirmations captured by these initiatives. While which specific rights or principles will gain prominence over time remains to be seen, a deeper understanding of events such as the 2013 Snowden disclosures may provide a powerful model for understanding their development. As new attempts to explore the issue of digital constitutionalism surface, we also expect to develop a fuller picture of the relationship between these efforts and concrete social change, and hope that our efforts in this paper serve as a valuable tool in that process.

and are carried by a broad consensus, while human rights law is a comparably static body of rules rooted in the rule of law. 


\section{Bibliography}

African Declaration Coalition. "African Declaration on Internet Rights and Freedoms." Last modified August 5, 2015. http://africaninternetrights.org/declaration-container/declaration/.

Association for Progressive Communications. "Internet Rights Charter." Last modified November 2006. https://www.apc.org/node/5677.

Association for Progressive Communications. "Internet Rights are Human Rights." Last modified May 2011. https://www.apc.org/en/pubs/briefs/internet-rights-are-human-rights-claims-apc-human-.

Anderson, Nate. "New Internet Bill of Rights Contender Comes from... Pirates?" Ars Technica, December 11, 2009. Accessed August 5, 2015. http://arstechnica.com/tech-policy/2009/12/newinternet-bill-of-rights-contender-comes-from-pirates/.

Barlow, John Perry. “A Cyberspace Independence Declaration.” Last modified February 9, 1996. https://w2.eff.org/Censorship/Internet_censorship_bills/barlow_0296.declaration.

Best Bits. "Post- WCIT statement by civil society organizations present at the workshop 'Governing the internet' held in Rio de Janeiro from November 26-28." Last modified December 15, 2012. http://bestbits.net/post-wcit-statement/.

Brazil Internet Steering Committee (CGI.br). "Principles for the Governance and Use of the Internet." Accessed August 5, 2015. http://www.cgi.br/principles-for-the-governance-and-use-of-the-internet/.

British Library. "My Digital Rights.” Accessed August 5, 2015. http://www.bl.uk/my-digital-rights.

Camera dei deputati [Italy]. "Declaration of Internet Rights.” Last modified July 28, 2015.

http://www.camera.it/application/xmanager/projects/leg17/commissione_internet/testo_definitivo_ing lese.pdf.

Castro, Daniel. "Opinion: A Declaration of the Interdependence of Cyberspace." Computerworld, February 8, 2013. Accessed August 5, 2015.

http://www.computerworld.com/article/2494710/internet/a-declaration-of-the-interdependence-ofcyberspace.html.

Chenou, Jean-Marie. "Is Internet governance a democratic process? Multistakeholderism and transnational elites." Paper presented at the ECPR General Conference 2011, Reykjavík, Iceland, August 25-27, 2011.

Gagnier, Christina M., and Gagnier Margossian. “A Social Network Users' Bill of Rights.” Last modified March 26, 2011. http://www.w3.org/2011/track-privacy/papers/GagnierMargossian.pdf.

Civil Society and the Trade Union Advisory Committee to the OECD. "Seoul Declaration to the OECD Ministerial Conference on the future of the Internet economy." Last modified June 16, 2008. http://thepublicvoice.org/events/seoul08/seoul-declaration.pdf.

"Recommendation CM/Rec(2012)4 of the Committee of Ministers to Member States on the Protection of Human Rights with Regard to Social Networking Services." Council of Europe, April 4, 2012. 
Council of Europe. "Declaration by the Committee of Ministers on Internet governance principles." Last modified September 21 2011. https://wcd.coe.int/ViewDoc.jsp?id=1835773.

Davies, Todd. "Digital Rights and Freedoms: A Framework for Surveying Users and Analyzing Policies." Paper presented at the 6th annual Conference on Social Informatics, Barcelona, November 10-13, 2014.

Doria, Avri. "Use [and Abuse] of Multistakeholderism in the Internet." In The Evolution of Global Internet Governance - Principles and Policies, edited by Roxanna Radu, Jean-Marie Chenou, and Rolf H. Weber. Berlin: Springer, 2014.

Electronic Frontier Foundation. "A Bill of Privacy Rights for Social Network Users.” Last modified May 19, 2010. https://www.eff.org/deeplinks/2010/05/bill-privacy-rights-social-network-users.

Electronic Frontier Foundation. "Mobile User Privacy Bill of Rights." Last modified March 2, 2012. https://www.eff.org/deeplinks/2012/03/best-practices-respect-mobile-user-bill-rights.

Ello. “The Ello Bill of Rights for Social Network Users.” Last modified August 4, 2015. https://billof-rights.ello.co/.

FC Forum. "Charter for Innovation, Creativity and Access to Knowledge." Accessed August 5, 2015. http://fcforum.net/en/charter.

Fitzgerald, Brian. “Software as Discourse.” Alternative Law Journal, 25; 24(3) 1999: 144.

Free Press and the Free Press Action Fund et al.. "Declaration of Internet Freedom." Accessed August 5, 2015. http://www.internetdeclaration.org/freedom.

Gasser, Urs, Ryan Budish, and Sarah Myers West. "Multistakeholder as Governance Groups: Observations from Case Studies.” Berkman Center Research Publication No. 2015-1. January 14, 2015. Available at SSRN: http://ssrn.com/abstract=2549270 or http://dx.doi.org/10.2139/ssrn.2549270

Geneva Summit for Human Rights and Democracy. "Geneva Declaration on Internet Freedom." Last modified March 9, 2010. http://www.genevasummit.org/outcome/2/2010.

Global Multistakeholder Forum on the Future of Internet Governance. "NETmundial Multistakeholder Statement." Last modified April 24, 2014. http://netmundial.br/wpcontent/uploads/2014/04/NETmundial-Multistakeholder-Document.pdf.

Global Network Initiative. "Principles on Freedom of Expression and Privacy." Accessed August 5, 2015. https://www.globalnetworkinitiative.org/principles/index.php.

Green Party of Aotearoa, New Zealand. "Internet Rights and Freedoms Bill.” Last modified April 22, 2014.

https://home.greens.org.nz/sites/default/files/internet_rights_and_freedoms_bill_accompanying_docu ment_0.pdf. 
Hart, H. L. A., The Concept of Law ( $2^{\text {nd }}$ Edition), Oxford, Clarendon Press, 1998.

Internet Governance Forum (United Nations). "Internet Rights \& Principles Dynamic Coalition." Accessed August 5, 2015, http://internetrightsandprinciples.org/wpcharter/.

Internet Rights and Principles Dynamic Coalition. "Internet Rights and Principles Charter." Accessed August 5, 2015. http://internetrightsandprinciples.org/wpcharter/.

Issa, Darrell. “A Digital Citizen's Bill of Rights.” Last modified on August 5, 2015.

http://keepthewebopen.com/digital-bill-of-rights.

iRights Coalition. "iRights.” Accessed August 5, 2015. http://irights.uk/the_irights/.

Jørgensen, Rikke Frank. “An Internet Bill of Rights?” In Research Handbook on Governance of the Internet, edited by Ian Brown, 353-372. Cheltenham: Edward Elgar Publishing, 2013.

Liddicoat, Joy, and Avri Doria. "Human Rights and Internet Protocols: Comparing Processes and Principles."

Internet Society Briefing Papers (2012).

Magna Carta for Philippine Internet Freedom (MCPIF) [English Translation]. S. No. 53, 16th Congr. (2014). http://democracy.net.ph/full-text/.

Mashable. "A Digital Bill of Rights for the Internet, by the Internet." Last modified August 12, 2013. http://mashable.com/2013/08/12/digital-bill-of-rights-crowdsource/.

Messmer, Ellen. "Educom drafts model net 'bill of rights'." Network World, November 16, 1992, 4748.

Musiani, Francesca. "The Internet Bill of Rights: A Way to Reconcile Natural Freedoms and Regulatory Needs?” SCRIPTed: A Journal of Law, Technology and Society 6(2009): 504-15.

Necessary and Proportionate. "International Principles on the Application of Human Rights to Communications Surveillance." Last modified May 2014.

https://en.necessaryandproportionate.org/text.

Norwegian Communications Agency. "Network Neutrality: Guidelines for Internet Neutrality (2009)." Last modified September 4, 2013. http://eng.nkom.no/technical/internet/net-neutrality/netneutrality/_attachment/9222?.ts=1409aa375c1.

OECD. "Communiqué on Principles for Internet Policy-Making: OECD High Level Meeting on the Internet Economy, 28-29 June 2011.” Accessed August 5, 2015.

https://www.oecd.org/internet/innovation/48289796.pdf.

People's Communication Charter Coalition. "People's Communication Charter." Last modified December 22, 1999. http://www.pccharter.net/charteren.html.

Public Knowledge. ““”A Timeline of Net Neutrality.” Accessed September 15, 2015, http://whatisnetneutrality.org/timeline. 
Public Knowledge. "Marco Civil da Internet [English Translation].” Last modified May 27, 2014, https://www.publicknowledge.org/documents/marco-civil-english-version.

Public Voice. "The Madrid Privacy Declaration: Global Privacy Standards for a Global World." Last modified November 3, 2009. http://thepublicvoice.org/madrid-declaration/.

Reform Government Surveillance Coalition. "Global Government Surveillance Reform." Accessed August 5, 2015. http://www.reformgovernmentsurveillance.com/.

Rodotà, Stefano. "Una Costituzione per Internet." La Repubblica Tecnologia \& Scienze, June 28, 2006. Accessed August 4, 2015.

http://www.repubblica.it/2006/06/sezioni/scienza_e_tecnologia/regole-internet/regole-internet/regoleinternet.html.

Rosen, Jeffrey. “The Right to Be Forgotten.” Stanford Law Review Online 64 (2012): 88-92. http://www.stanfordlawreview.org/online/privacy-paradox/right-to-be-forgotten.

Fitzgerald, Brian. "Software as Discourse." Alternative Law Journal 25 (1999). Last modified July 2, 2015. http://www5.austlii.edu.au/au/journals/AltLawJ1/1999/25.html.

Rothkopf, David. "Rights 2.0.” Foreign Affairs 210 (2015): 66-7.

Smarr, Joseph, Marc Canter, Robert Scoble, and Michael Arrington. "A Bill of Rights for Users of the Social Web.” Accessed August 5, 2015. http://www.template.org/?page_id=599.

Suzor, Nicholas. "Digital constitutionalism and the role of the rule of law in the governance of virtual communities." PhD diss., Queensland University of Technology, 2010.

Tech Freedom et al.. "Declaration of Internet Freedom.” Accessed August 5, 2015. http://declarationofinternetfreedom.org/.

UK Liberal Democrats. "Protecting your data online with a Digital Rights Bill." Last modified on April 11, 2015. http://www.libdems.org.uk/protecting-your-data-online-with-a-digital-rights-bill.

United Nations, Organization of American States, Organization for Security and Co-operation in Europe, African Commission on Human and Peoples' Rights. "Joint Declaration Concerning the Internet." 2001. https://www.oas.org/en/iachr/expression/showarticle.asp?artID=848\&IID=1.

Waldron, Jeremy. “Constitutionalism: A Skeptical View”, Scholarship @ Georgetown Law (Georgetown University Law Center, 2010). Accessed 4 November 2015.

http://scholarship.law.georgetown.edu/cgi/viewcontent.cgi?article=1002\&context=hartlecture.

Waluchow, Wil. "Constitutionalism," in The Stanford Encyclopedia of Philosophy, ed. Edward N. Zalta (Spring 2014 Edition). Accessed November 4, 2015.

http://plato.stanford.edu/archives/spr2014/entries/constitutionalism/.

World Summit on the Information Society (ITU). "Declaration of Principles." Last modified December 12, 2003. http://www.itu.int/wsis/docs/geneva/official/dop.html.

World Economic Forum. "Informed Societies: Towards a Code of Conduct for Government Leaders." Last modified June 21, 2012. 
http://www3.weforum.org/docs/WEF_GAC_InformedSocieties_CodeConductGovernmentLeaders_S ummary 2012.pdf. 